\title{
A Review Paper on Experimental Study on Stabilization of Soil Subgrade by Adding Stone Dust
}

\author{
Deepak Kumar1, Magandeep Bishnoi² \\ ${ }^{1}$ M.Tech Scholar, ${ }^{2}$ Assistant Professor \\ 1,2Department of Civil Engineering, Om Institutes of Technology \& Management, Juglan Hisar, Haryana, India
}

\begin{abstract}
How to cite this paper: Deepak Kumar | Magandeep Bishnoi "A Review Paper on Experimental Study on Stabilization of Soil Subgrade by Adding Stone Dust" Published in International Journal of Trend in Scientific Research and Development (ijtsrd), ISSN: 24566470, Volume-3 | Issue-4, June 2019, pp.1063-1064, URL: https://www.ijtsrd.c om/papers/ijtsrd24 043.pdf

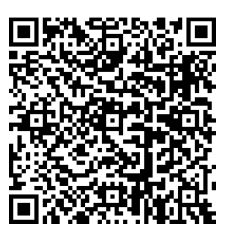
IITSRD24043
\end{abstract}

Copyright (c) 2019 by author(s) and International Journal of Trend in Scientific Research and Development Journal. This is an Open Access article distributed under the terms of the Creative Commons

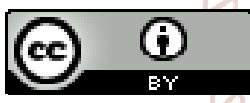
Attribution License (CC BY 4.0) (http://creativecommons.org/licenses/ by $/ 4.0$ )

\section{ABSTRACT}

Subgrade is the lower most layer of the pavement construction. So soil subgrade should be capable strong to carry load coming from the upper layer. Many stabilization techniques are adopted to improve the stability and bearing capacity of soil. In this study we use Kota stone dust that is easily available in Rajasthan state as a waste form. In this stone dust we find that nearly $30 \%$ lime is available so can be used for it like as lime stabilization. By adding Kota stone bearing capacity increase of the soil.

Keywords: Kota stone dust, SPT test, UCS test

\section{INTRODUCTION}

Highway pavement construction two types

Rigid pavement

$>$ Flexible pavement

In both the pavement construction bottom layer is soil subgrade. That are enough strong to take upper layer load.

So soil stabilization is carried out it make more powerful. Soil stabilization increase bearing capacity of soil, by soil stabilization maximum dry density of soil will be increase and soil become impermeable

\section{Review of literature}

Many studies are carried out for the soil stabilization.
Chandra et al 2015- In this study rice husk is added in soil for increase the stabilization of the soil. By this bearing capacity and CBR value of the soil are increased.

Deepiya et al 2016- in this study used the marble dust for increasing the soil bearing capacity. Marble dust makes soil more stabiles.

Kumar et al 2017 - Black cotton soil are more swelling and shrinkage property by adding water and load carrying capacity are low of black soil. So it makes more loads carry capacity added dust practical.

\section{DESIGN METHODOLOGY \\ SPT Test \\ Standard protector test are carried out for the soil.}

\section{Size of the Test Specimens}

Standard size of mould taken and soil fill in 3 layers in the mould by tamping 25 blows of each layer by tamping rod. Than soil sample is taken from the mould water content is determined for this soil. Than with the help of formula maximum dry density is calculated

$p d=p / /(1+w)$
Here $p d=$ Maximum dry density

$\mathrm{w}=$ water content in the soil

\section{UCS Test}

Unconfined compassion test are carried out for the clayed soil by adding different portion of kota stone that is in Initially add $2 \%$ of Kota stone check the unconfined compressive strength of clayed soil. Now further percentage of kota stone will be increase that is added $4 \%$ and next sample increase $6 \%, 8 \%, 10 \%$ and $12 \%$ added .And each mix unconfined compression strength is calculated.

\section{Objectives of the Study}

The study on use of Kota stone in clayey soil conducting laboratory test are carried out. The main objectives of study are:

1. To increase the bearing capacity of subgrade soil by adding kota stone dust

2. To determine the maximum dry density of clayey soil by adding different percentage of Kota stone slurry.

3. To determine the unconfined compression strength of soil by adding varying percentage of kota stone dust

4. To determine the optimum moisture content of soil subgrade. 
The purpose of this research was to study that Kota stone how much effective to increase the load carrying capacity of soil subgrade when it added in clayey soil. Because large percentage of lime are available in stone dust.

\section{REFERENCES}

[1] MN Rao and JS Jha 2005. "Swelling index of clay due to montmorrline" V. 26, No.2, February 2005, pp. 58-60.

[2] Yen and Akash (2002). "stabilization of clayey soil by adding admixture " Cement and Concrete Composites, volume 20 , No. 5, 2002, pp. 270-274.

[3] Vishal sah and Piyush sah 1990. "Determination of optimum moisture content and maximum dry density of soil" volume 5 Nov-Dec Page 172-175
[4] Buntial , F., "Soil Stablization by adding lime and rice husk" Mate'riaux et. Construction, Vol. no. 33, September-October 2005,pp 504-508.

[5] Hement sedeghi and paul chandarn (2003). "soil stabilization by adding bitumen and lime ," Soil Research, V.32, No.1, pp. 126-133.

[6] Subha and Tangle . "Modified the CBR value of soil adding coire fibre" soil State of the Practice National Review September 2008," page no 111-116.

[7] Morth specification

[8] Kumar R Rao and S. kumar "Increase the dry density of soil subgrade by adding mineral" international jouranal volume 2 pp 1112-118.

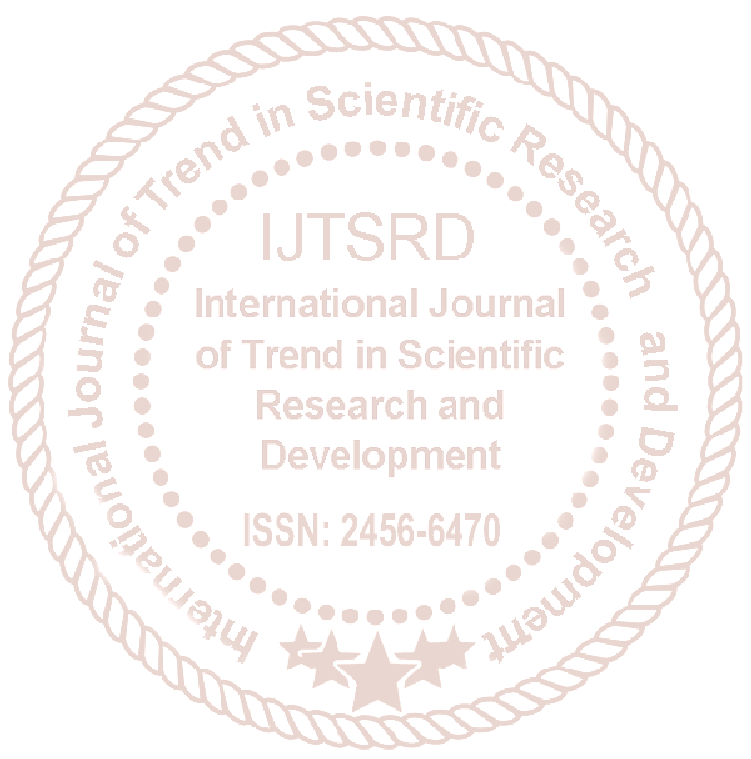

